\title{
RUÍDOS E SILÊNCIOS DE UM CORPO NA CIDADE: PARADOXOS DA PRODUÇÃO DA DIFERENÇA NO CONTEMPORÂNEO
}

\author{
CLATTER AND PEACE OF A BODY IN THE CITY: PARADOXES OF THE PRODUCTION OF \\ DIFFERENCE IN THE CONTEMPORARY \\ RUIDOS Y SILENCIOS DE UN CUERPO EN LA CIUDAD: PARADOJAS DE LA PRODUCCIÓN DE \\ LA DIFERENCIA EN EL CONTEMPORÁNEO
}

\author{
Elton Silva Ribeiro* \\ Luis Antonio dos Santos Baptista*
}

\begin{abstract}
RESUMO
O tema da inclusão social e do combate às práticas de intolerância ao diverso são questóes marcantes nas ações da saúde mental da atualidade. A cidade, nesses projetos, ganha destaque como espaço de consolidação de direitos civis, porém a polissemia política do que seja a urbe, a diferença ou o direito civil nem sempre estão presentes. Este artigo objetiva investigar a produção da diferença na experiência urbana, assim como as questóes éticas inerentes a essa produção. À luz das contribuições teóricas de Roland Barthes e Michel Foucault, entre outros autores, pretende refletir sobre os paradoxos presentes na afirmação da potência da diferença no dia a dia de uma cidade, assim como a neutralização de sua força capaz de problematizar as ações inclusivas da saúde mental. $\mathrm{O}$ aporte ético do artigo aposta na potência da diferença em produzir encontros desestabilizadores com a loucura, com a cidade e com o presente. Encontros que possam afirmar a força política do inacabamento que põe à prova a compacidade das convicções inspiradas em otimismos ou pessimismos paralisantes da atualidade.
\end{abstract}

Palavras-chave: Política. Diferença. Cidade. Subjetividade.

\footnotetext{
ABSTRACT

The subject of social inclusion and the struggle against practices of intolerance are significant issues to mental health actions. In these projects, the city arises as a locus of civil rights consolidation, although the political polysemy of the city, the difference or the civil rights may be not under

Texto recebido em 8 de junho de 2013 e aprovado para publicação em 3 de junho de 2015.

Mestre em Psicologia pelo Programa de Pós-Graduação em Psicologia da Universidade Federal Fluminense (UFF); psicólogo. Endereço: Rua Pedro de Carvalho, 318, ap. 402 - Méier, Rio de Janeiro-RJ, Brasil. CEP: 20725-232.

E-mail: elton_rb@yahoo.com.br.

* Professor titular do Departamento de Psicologia da UFF; pesquisador do CNPQ. Endereços: UFF, Departamento de Psicologia, Campus do Gragoatá, Bloco O - São Domingos, Niterói-RJ, Brasil. CEP: 24220-008; ou Rua das Laranjeiras, 361, ap. 304 Laranjeiras, Rio de Janeiro-RJ, Brasil. CEP: 22240-005. E-mail: baptista509@gmail.com.
} 
consideration. This paper aims to investigate the production of difference in urban experience, as well as the ethical implications involved in this process. Inspired by the theoretical contributions of Roland Barthes and Michel Foucault, among others, this paper intends to discuss the paradoxes present in affirming the potency of difference on the daily life of a city, as well as the impoverishment of its questioning power over the inclusive actions in mental health. This paper's ethical supply wages on the potency of difference in producing destabilizing encounters with madness, with the city and with the present. Encounters that may affirm the political power of the unfinishedness that makes vulnerable the compactness of beliefs inspired by paralyzing optimisms and pessimisms nowadays.

Keywords: Politics. Difference. City. Subjectivity.

\section{RESUMEN}

La temática de la inclusión social y del combate a las prácticas de intolerancia al diferente son cuestiones notables en las acciones actuales de salud mental. La ciudad en esos proyectos se destaca como espacio de consolidación de derechos civiles, aunque la polisemia política de lo que sea la urbe, la diferencia o los derechos civiles casi nunca están presentes. Ese artículo intenta indagar la producción de la diferencia en la experiencia urbana, como también las cuestiones éticas inherentes a esa producción. Influenciado por las contribuciones teóricas de Roland Barthes y Michel Foucault, entre otros autores, desea reflexionar sobre las paradojas presentes en la afirmación de la potencia de la diferencia en el contexto diario de una ciudad, como también la neutralización de su fuerza capaz de problematizar las acciones inclusivas de salud mental. El aporte ético de este artículo apuesta en la potencia de la diferencia para producir encuentros desestabilizadores con la locura, con la ciudad y con el presente. Encuentros que puedan afirmar la fuerza política del inacabamiento que pone a prueba la compacidad de las convicciones inspiradas en optimismos o pesimismos paralizantes de la actualidad.

Palabras clave: Política. Ciudad. Diferencia. Subjetividad.

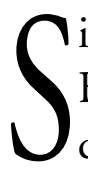

ilenciar e calar não tinham o mesmo significado na Antiguidade. Roland Barthes (2003, p. 50) adverte-nos que o silêncio e o calar-se teriam nuances diferenciadas: "tacere, como silêncio da fala, opõe-se a silere, como silêncio da natureza”. Silere seria empregado para a noite, o mar e o vento; silêncio que afirmaria intensidades das forças naturais, ou o que ainda não surgiu, o ainda não, ou o que despontará; silere também seria o sentido da morte. O silere não se restringiria a natureza. Nuances desse silêncio estariam também na literatura 
e na política. Para Maurice Blanchot (2005, p. 321), "Uma obra literária é, para aquele que sabe penetrar nela, uma preciosa morada de silêncio, uma defesa firme e uma alta muralha contra essa imensidade falante que se dirige a nós, desviando-nos de nós”. Este artigo objetiva refletir sobre a diferença como silere e tacere, isto é, o silêncio da diferença que escapa da captura que a aprisiona em significados definitivos, a que vai ao encontro do ainda não, ao que virá, em contraste com a diferença ruidosa, plena de significados claros e previsíveis encontrada nas práticas do poder que faz falar; estridência do eu solitário, das confissões íntimas, das identidades imobilizadas em si mesmas; ruídos imunes a qualquer deslocamento advindos da potência do inesperado. Diversidade imóvel, intocável quando fixada na soberania das suas bordas. Para Blanchot (2005, p. 330), "A poesia se torna então o que seria a música, se reduzida à sua essência silenciosa: um andamento e um desdobramento de puras relaçóes, isto é mobilidade pura". Mobilidade transgressora de compactas fronteiras, de discursos conclusivos presentes na produção do outro ou de um futuro carregado de esperanças ou de pessimismos imóveis. Desejamos pensar sobre esses silêncios da diferença como paradoxos tramados na cidade; no uso de cenas ordinárias do dia a dia, objetivamos problematizar dilemas éticos sobre a criação e o aniquilamento da força da alteridade.

Nas produções da diferença no contemporâneo, trajetos que se dão sobre o chão marcado da urbe comportam forças que extrapolam o domínio do perceptível. Passos na rua ressoam lutas, desejos de ordem, sandices, planos e acasos. Corpos no contato com a cidade não estariam imunes à história nem esta a eles. Ao andar por ruelas sujas, sobre elevados ou por um piso liso e asséptico, o transeunte carrega modos distintos de relacionar-se com a cidade e com o outro. As cidades incitam mobilidades adequadas ao corpo saudável tutelado pela ordem urbana, o equilíbrio das emoções, porém algo poderá suceder inesperadamente na urbe. Despossuído do atrito dos pés com o chão a queda de um corpo ao flutuar pode nos narrar histórias inusitadas. Histórias de diferenciados silêncios.

$\mathrm{Na}$ cidade nordestina que se vende como capital da qualidade de vida, cenas veiculadas por jornais locais dizem algo sobre relaçôes com a alteridade no contemporâneo. No embate de forças que compõe o cotidiano das urbes, diante do acúmulo crescente de informações e de saberes, mais do que cenas, acontecimentos que interpelam o presente insistem em ser produzidos; teimam em provocar rupturas e, aos poucos, abalam formas endurecidas dos saberes convictos. Existências simples, sem nenhuma glória, por astúcias ou até por um descuido, frequentemente questionam mundos naturalizados da vida ordinária. Algumas narrativas, ao diferirem das informaçōes por não terem compromisso com "fatos comprováveis", podem intensificar sutis abalos. 
Em Aracaju, um episódio provocou aturdimento. Singular, imprevisível, retirou as coisas de seus lugares e fez entrever outros possíveis. Um corpo, ao cair, provocou desassossegos. O barulho ecoado no encontro deste com o chão, contudo, teve seu volume diminuído, quando não emudecido. Fora ouvido por muitos como pedido por segurança, previsão confirmada, contribuição da loucura com mais um dado estatístico. Os efeitos desta vida breve traduzida em informação jornalística desvaneceram-se quase imediatamente. Uma mulher cai do viaduto com seus silêncios; transeuntes fazem falar o corpo imóvel agora impedido de silenciar. O que esse episódio tem a nos dizer sobre o silenciar e o calar de um corpo? Qual trama da produção da diferença estaria sobre o asfalto?

\section{UM CORPO NA CIDADE}

É início da noite em uma cidade que é muitas e que poderia ser tantas outras. Ela fervilha alimentada por passos, barulhos, cheiros, incômodos, acasos, desejos. Transeuntes, ora apressados, ora se deixando afetar por inúmeras temporalidades, aparecem por todos os lados e, ao caminharem para as mais variadas direções, sentem na pele os poluentes que se adensam e misturam-se ao clima típico de uma cidade ao nordeste do País. O dióxido de carbono e o calor advindo dos motores pairam no ar e provocam a vontade em alguns de logo chegar a seus destinos. Já outros parecem traçar caminhos ao acaso; em suas desnorteantes imprevisibilidades, são chamados por tempos e espaços metrificados a compor uma harmônica sinfonia urbana. Sobre um viaduto que corta uma das maiores avenidas da cidade, automóveis passam acelerados, mas logo são obrigados à lentidão, devido ao tráfego intenso. Na maioria dos veículos, o que convoca a atenção de seus condutores são outros autos que, em determinados momentos, obrigam a reduzir a velocidade, em outros, oferecem a chance de uma ultrapassagem. A temperatura amena produzida pelo ar condicionado e o som emitido pelos alto-falantes diminuem a presença incômoda da rua.

$\mathrm{Na}$ grande avenida que liga trechos importantes e de crescente valorização da cidade, passantes outros em seus trajetos caminhados sentem o calor e, de forma mais vulnerável, a imprevisibilidade da urbe. A harmônica sinfonia urbana fracassa. Debaixo do viaduto pintado com cores fortes, algo convida a demorarse. Uma cena destoa e produz rallentando em um ritmo que, por diversas vezes, captura. Produz paradas e suscita pensamentos. A cena, que deixará de ser apenas cena, também desacomoda. Dezenas de pessoas amontoam-se em torno de algo que, numa rápida olhada, não é de fácil reconhecimento. Um homem com uma câmera, outro com um microfone em mãos já se encontram presentes no local. Parecem desejar registrar algo, transformar em informação. $\mathrm{O}$ automóvel do 
órgão de fiscalização de trânsito e uma faixa de listas amarelas e pretas isolam um pequeno espaço; impedem que se chegue mais próximo. Curiosidade, conjecturas, diagnósticos, tristeza e até previsões confirmadas perpassam os olhos daqueles que observam. Em meio a tudo, um plástico preto, uma pedra e uma bolsa branca compõem o que a baixa luminosidade do local dificultaria ainda mais identificar não fossem as luzes projetadas pela câmera do cinegrafista e pelo farol do carro. Por baixo do grande pedaço de plástico, ao lado da bolsa e do que parece um guarda-chuva, permanece um corpo imóvel.

Debaixo do viaduto, o rastro de sangue deixado por aquele corpo que se deixou cair, mesmo após diversas tentativas de limpeza e camadas de outras informações, não fora eliminado. $\mathrm{O}$ sangue se espraiou pelas ruas, adentrou territórios seguros; penetrou nas artérias pulsantes da cidade. Tal sangue aqui não diz da mistura de substâncias que corre pelas veias, mas de uma mistura híbrida formada por histórias heterogêneas. Talvez por portar uma estranha força, insistia em provocar transtornos. Teimou em incomodar relaçôes estabelecidas, boas vontades, indiferenças, credos. O corpo, ao cair, não deslocara somente uma massa de ar; embora tendo sido abafado, provocou ruídos que reverberaram. Sem se preocupar em confirmar ou refutar diagnósticos, interpelava o que a cidade tinha a dizer sobre a diferença. A loucura deixava de ser uma previsível personagem; desmanchava seus limites, convocando ao questionamento de certezas e incertezas em suas lidas diárias. O silêncio daquele corpo reverberava uma singular mobilidade.

Sob o plástico preto, destes que são usados para cobrir algumas cargas de caminhão, o corpo registrado pela imprensa permanecia imóvel. A bolsa branca e um guarda-chuva ao lado do corpo pareciam dizer se tratar de uma mulher. O guarda-chuva estava aberto, mas não era dia de chuva, será que, por se crer leve, tentara flutuar? Ao retirarem o que cobria aquilo que se julgava uma forte imagem para os jornalistas e curiosos, ela fora revelada; apesar de outras feiçôes, era conhecida, tempos antes a retiraram do anonimato e lhe carregaram de sentidos.

O ambiente fechado, climatizado, a iluminação artificial refletindo no chão claro e limpo geravam a sensação de segurança e conforto. Parecia não deixar a rua entrar. $\mathrm{O}$ jardim fabricado e visualizado através de enormes e nítidos vidros indicava a exaltação da natureza. Famílias, casais de namorados, solitários, encontravam o destino que, para a maioria, é de conforto e lazer; lá passeavam sem pressa consumindo sonhos vendidos em embalagens decoradas. Rostos sorridentes, vitrines com roupas da última estação, vidas a serem vividas nas grandes telas e redes de fast food convidavam todos a se sentir bem e a consumir. 
No shopping mais frequentado da cidade de Aracaju, a aparência daquela mulher maculava a assepsia e a atmosfera harmoniosa do local. O estranho insistia em turvar aquele espaço que desprezava as misturas da cidade. A rua atravessava paredes e incomodava. Com suas diversas sacolas de compras, ela poderia passar despercebida como as centenas de pessoas que circulam todos os dias nesses espaços. Mas a sua aparência incomum, o seu silêncio a retiraram do anonimato. $\mathrm{O}$ rosto coberto por diversas camadas de base escondia seus traços, contrastava com a pele morena que se deixava entrever pelo seu pescoço. Com cabelo crespo, penteado singular, roupas gastas, uso constante de óculos escuros, ela passeava pelo ambiente higienizado destoando do padrão estético da maioria de seus frequentadores. Devido à presença constante, não demorara muito para ser dito na cidade que uma senhora louca com visual extravagante circulava pelo shopping.

Passeava pelo local quase todos os dias com sacolas em mãos ou em um carrinho de compras; alguns afirmavam, com certo espanto, que ela teria dinheiro, alguma fonte de renda. Às vezes, fazia um lanche em uma das diversas lanchonetes, compras em um supermercado e, aos poucos, tornava-se conhecida pelos funcionários do local. Porém quase não falava, comunicava-se, muitas vezes, através de bilhetes. Normalmente bilhetes já prontos e que, em algumas ocasióes, quando interrogada, eram entregues, mesmo sem fazer algum sentido para quem a estava interrogando. Usava quase sempre as mesmas roupas e exalava um acre odor devido à grande quantidade de base usada no rosto.

A estranha personagem provocava curiosidades, mas não demorou muito e passou a gerar incômodos no local. Curiosidade, assombro, ojeriza, pena, dúvidas, intenções de normalização. A presença do outro, de alguma forma, perturbava o espaço que se queria previsível. A rua, aqui figurada pela sua imprevisibilidade e pela possibilidade de encontros que propicia, invadia o interior higienizado do shopping. Como nos conta Caiafa (2002):

As cidades geram um poderoso espaço de exterioridade que se opõe tanto ao interior dos espaços fechados quanto à interioridade do sujeito. A heterogeneidade ali ativa dispersa focos de identidade e as recorrências do familiar, introduzindo, portanto, variação nos processos subjetivos (p. 92).

Ela passou então a ser conhecida por grande parte da cidade; quem não a conhecia, pelo menos ouvira falar. Recebeu apelido, "Véia do Shopping", despertou a curiosidade de muitos, e assim ganhou comunidades em sites de relacionamentos, notícias em jornais locais e até, tempo depois, uma música. Mesmo nada dizendo, passou a ser um espetáculo. Em breve, curiosos, jornais, 
profissionais da saúde passavam a produzir uma história para ela e a buscar um "sentido" para aquilo que viam... Era enfermeira e também teóloga. E, há cerca de oito anos, um acontecimento trágico em sua vida a teria deixado "desorientada". Entre sentimentos de repulsa, pena, medo e curiosidade, tornouse figura popular na cidade. A loucura, agora "explicada", habitava o shopping. O seu silêncio gradativamente era emudecido.

Algum tempo passou, e então noticiaram que, após inúmeras tentativas, profissionais da rede de saúde mental da cidade, conseguiram produzir algum vínculo com a curiosa personagem. Disse uma psiquiatra da rede que foram dois anos de pequenas incursões até que ela concordasse em visitar o Centro de Atenção Psicossocial. Um conhecido canal de notícias da internet noticiou: "A Véia do Shopping muda de vida"; estampando a manchete com uma foto dela de cabelos cortados, sem base no rosto e com roupas mais comuns. Além disso, afirmava que uma força-tarefa composta de profissionais da saúde, familiares e uma igreja evangélica foram os responsáveis pela "reviravolta" em sua vida. Silere e tacere, o silenciar e o calar-se ocupavam os traçados de Aracaju.

Após esse momento, Maria José Menezes Santos, de 60 anos, teve parte de sua vida capturada e exposta. Uma tia contou aos jornais qual era a sua "história". Linhas sobre sua vida, possíveis motivos para o "surto" foram articulados, e ela então deixou de ser a estranha anônima para tornar-se a mulher vulnerável que sofria, portadora de transtorno mental. Faziam-na ruidosamente falar. Os espaços e pessoas não suportavam a mácula daquela diferença. Agora "sob cuidado", diziam que ela estava em processo de "cura". Maria José era incitada a confessar o que era, a despossuir a potência do seu silêncio.

Passou um pouco mais de dois anos e mal se ouvira falar dela. No dia 20 de junho do ano de 2011, divulgou-se em vários jornais que havia sido encontrado um segundo corpo debaixo do viaduto em menos de um mês. Outro suicídio. Era ela. Muitos se questionaram surpresos o porquê da morte depois do tratamento psicológico, do reencontro com a família e com a Igreja. Alguns disseram que deveria estar passando por uma depressão. Outros, que era louca e aí "já viu né?". Especulou-se novamente. Sua morte agora era o alvo. Ao saberem da notícia, muitos demonstraram preocupação com a insegurança, pois não seria o primeiro caso do ano de suicídio naquele viaduto. Solicitavam uma grade de proteção nos viadutos para que episódios assim não mais ocorressem. Perguntas, pena, lástima, compaixão, pedido por segurança. $\mathrm{O}$ barulho do corpo ao chocar-se com o chão não foi ouvido... E novamente pediram por mais segurança. $\mathrm{O}$ que o silêncio desse corpo tem a dizer para a cidade? 
Afinal, não será um dos traços fundamentais da nossa sociedade o fato de o destino tomar aqui a forma da relação com o poder, da luta com ou contra ele? O ponto mais intenso das vidas, aquele em que se concentra a sua energia, encontra-se efetivamente onde elas se confrontam com o poder, se batem com ele, tentam utilizar-lhe as forças ou escapar-lhe às armadilhas (Foucault, 1992, p. 99).

Distintos acontecimentos no cotidiano citadino trazem à cena o risco de neutralizações da força política da diferença no campo das ações inclusivas da saúde mental e das pesquisas em Ciências Humanas. Em muitas destas, aquilo que escapa tende a ganhar nome e a ser solicitado a permanecer preso em suas impermeáveis fronteiras. Produz-se, assim, uma história acabada, história de uma vida que diria respeito somente a ela mesma. Sob uma luz que os arranca da noite, do inominável, crianças, loucos, moradores de rua ganham aura de vilōes, vítimas, por vezes até de heróis, e são solicitados a confirmar a aura da diferença. Investidas biopolíticas (Foucault, 1988) atuam produzindo uma rede contínua que busca dar conta de cada pulsar de vida dizendo dos modos de se relacionar consigo mesmo e com a cidade, produzindo faltas, às vezes até excesso, àqueles que desviam. Em tal rede, discursos fortalecidos pelo saber científico, reproduzidos em pequenas práticas no cotidiano citadino, criam um domínio do "tolerável", fazem falar e evocam para tais corpos origens e destinos. Como escapar a práticas que, no anseio de incluir, de colocar o outro em evidência, acaba por retirar a radical força de alterização que se produz com a diferença? O que a existência da "Véia do Shopping" tem a dizer sobre o viver nas cidades contemporâneas quando palavras e silêncios perdem a intensidade de dizer sim à vida?

Foucault (1993), no prefácio à edição americana de "O anti-Édipo: capitalismo e esquizofrenia”, aponta a potência da obra de Deleuze e Guattari, tomando-a como ético-política e diz que, se quisesse fazer dessa obra um guia da vida cotidiana, poderia se propor um determinado número de princípios, essenciais ao exercício de uma vida não fascista; entre estes: "preferir o que é positivo e múltiplo, a diferença à uniformidade"; "liberar a ação política de toda forma de paranoia unitária e totalizante"; "não utilizar o pensamento para dar a uma prática política o valor de verdade" e "não se apaixonar pelo poder".

Tais princípios não parecem simples de ser adotados; colocam em risco o sujeito centrado do saber, pois ameaçam dissipar os seus contornos. Contudo, podem ser indicativos de modos que, como pesquisadores das ciências humanas, podemos operar para ir de encontro a esses fascismos que nos atravessam e comumente levam a procedimentos individualizantes, normalizadores e 
excludentes; mesmo que hoje estes tomem a forma de procedimentos inclusivos. Tomando emprestada uma indagação: "Estaríamos, aqueles ligados às ciências humanas e sociais, condenados a uma espécie de fascismo [...]? O fascismo de dizer do outro, pelo outro e, ademais, contra o outro - essa estratégia insidiosa e apequenadora da vida?" (Aquino, 2008). Que fascismos fariam falar a frequentadora do shopping que apostava no silêncio?

\section{HISTÓRIAS, NARRATIVAS E SILÊNCIOS}

Aqui irrompe um alerta de Foucault (1992) ressaltado no início de "A vida dos homens infames": "Isto não é uma obra de história". Ainda em outro trecho, o autor diz que seu escrito não agradará aos historiadores: "livro de humor e puramente subjectivo?” (p. 93). Foucault parece antecipar as críticas a um texto no qual, segundo ele mesmo, a regra obedecida para a reunião dos "fragmentos de vida" fora nada mais importante que uma emoção, um certo assombro ou outro sentimento qualquer cuja intensidade era difícil de justificar naquele momento.

Tais ditos parecem constituir mais uma estratégia do pensador francês. A Foucault fora atribuída a figura do filósofo em perigo e sabe-se de sua astúcia em circular pela academia, diante dos modos engessados de pensamento e das críticas possíveis. Mas, além disso, tal alerta chama a atenção para discursos que ditam o que deve ou não constituir a história. Por que, naquele momento em que Foucault escreve sua obra, um texto dizendo de vidas infames, reunindo relatos selecionados pela força de um sentimento que o acometeu, não compõe uma obra de história? E que história?

Deve-se ter em conta que a escrita da história não está descolada de certas práticas políticas (Gagnebin, 1994). Torna-se importante, portanto, pensar sobre como determinados usos da história podem interpelar modos estabelecidos de pesquisar em Ciências Humanas. De que forma, podem contribuir para outra postura ético-política diante da vida. Nessa direção, Walter Benjamin e Foucault fornecem pistas importantes, ao possibilitarem escapatórias de um tempo histórico homogêneo e linear. Por suas distintas historiografias, vislumbra-se o encerramento das grandes narrativas e a chance de encontrar no passado, mas também no presente, a possibilidade de um outro porvir. As cartas, passeios, o silêncio, os prazeres e provocaçôes de incômodos da "Véia Sergipana" colocavam à prova o desejo libertário de certas práticas de cuidado. A intensidade do seu cotidiano cortava, interrompia projetos humanistas indiferentes aos singulares perigos do agora. 
Foucault (1979) encontra em Nietzsche a inspiração do seu método historiográfico, a saber, a genealogia. O filósofo alemão critica a história tradicional, essa história que compõe linearidades e que acredita na existência de uma verdade pura presente na suposta origem dos acontecimentos. No lugar de tal história, propõe uma "história efetiva", história que não se apoia em nenhuma constância (pois nada no homem teria tal característica) e que se demora nos acasos dos começos.

A genealogia estaria interessada não na análise dos grandes feitos nem na busca da origem, mas na singularidade dos acontecimentos, naquilo que estes têm de único e agudo. O que interessa são os abalos, as surpresas, os acidentes que formaram o que hoje acreditamos ser verdade. O método genealógico serve como uma importante ferramenta para interrogar a aparente linearidade e calmaria daquilo que forma o presente. A genealogia pode perturbar, deslocar, intensificar os abalos, pois,

Ela não deixará nada abaixo de si que teria a tranquilidade asseguradora da vida ou da natureza; ela não se deixará levar por nenhuma obstinação muda em direção a um fim milenar. Ela aprofundará aquilo sobre o que se gosta de fazê-la repousar e se obstinará contra sua pretensa continuidade. É que o saber não é feito para compreender, ele é feito para cortar (Foucault, 1979, p. 28).

Nesta direção, as pesquisas foucaultianas partem de elementos de sua própria experiência e têm um caráter de crítica local, pois ele não visa à universalidade de seus ditos. Seu interesse era falar daquilo que atravessava o seu tempo, e isso se daria por meio de uma insurreição de saberes subordinados. Valorizava, então, os conhecimentos locais, desqualificados pelos discursos científicos, saberes dos homens comuns incapazes de unanimidade (Rodrigues, 2009).

Destarte, ele fora um dos filósofos que mais batalhou para incorporar a experiência a sua reflexão filosófica e historiográfica; experiência como algo de que se sai transformado, algo que se configura como um processo de "dessubjetivação". Em entrevista a D. Trombadori, em 1978, Foucault (1980) diz que seus livros são para ele experiências em seu sentido mais pleno. Livros-experiência em vez de livros-demonstração. De modo que os escreve sem saber direito o que pensar sobre o que vai escrever para, nesse empreendimento, transformar o seu pensamento e a si mesmo. 
Pretendo, isso sim, fazer, eu próprio, e convidar outros a fazê-lo comigo, uma experiência do que somos através de um determinado conteúdo histórico, daquilo que não apenas é o nosso passado, mas igualmente o nosso presente, uma experiência da nossa modernidade de tal maneira que dela saiamos transformados (Foucault, 1980, p. 27).

Uma experiência do que somos e do que estamos nos tornando, Foucault também irá dizer.

Albuquerque Júnior (2004) vêdiversos encontros entre os escritos foucaultianos e as narrativas dispostas pelo escritor tcheco Franz Kafka. Foucault, assim como Kafka, produziria histórias abertas, histórias que não findam em si mesmas. $\mathrm{O}$ ponto de partida de suas narrativas é um acontecimento, é sempre, portanto, uma prática que se altera e se diferencia da ordem. E é por essa ruptura, de um singular acontecimento que, ao desviar-se, instala uma descontinuidade na aparente "ordem natural" das coisas, que se pode perceber aquilo que é contínuo, a uniformidade das estruturas. Esse evento inaugural que põe a história em movimento (um jogo de forças que se subleva, uma morte, a metamorfose de um homem em um inseto) está sempre ligado a outros acontecimentos.

Este fato que se passa no mais íntimo dos cômodos de uma casa, o quarto, que parece ser apenas um acontecimento interior a uma vida, a uma família, a uma residência, vai deixando entrever conexões insuspeitas com processos externos, processos que se passam em outros lugares, que se passam em outros tempos, que se passam com outras personagens (Albuquerque Júnior, 2004, p. 16).

Além disso, Kafka e Foucault falaram do intolerável do seu tempo, desse peso de identidades e burocracias a que o homem comum é submetido cotidianamente. Falaram de um mundo onde a disciplina age nos corpos dos homens semelhante à ação das finas agulhas de cristal que inscrevem na carne dos presos suas sentenças, narrada no conto "Na colônia penal". Porém, para eles, essas estruturas não são determinantes, pois elas não impedem que, por uma mínima prática, produza-se um acontecimento desviante, que um simples acaso possa instaurar novos processos e fazer com que os sujeitos possam se metamorfosear. Ambos os pensadores indicam, portanto, a possibilidade de encontrar frestas, da construção de saídas para outros mundos possíveis (Albuquerque Júnior, 2004). Desse modo, argumentam que uma das tarefas do pesquisador é estar atento aos acontecimentos, estar atento às interpelaçôes do seu presente. 
"Vocês não têm o direito de menosprezar o presente", diz Baudelaire, uma das consciências mais agudas de seu tempo, aos pintores de sua época. Baudelaire exemplificaria a atitude de modernidade, segundo Foucault (2008), não por pertencer inteiramente ao seu tempo, mas por estabelecer com este uma atitude de distanciamento que o permite perceber aquilo que há de "heroico" no presente, permite transformá-lo captando-o naquilo mesmo que ele é. Essa relação diferente com o presente surgiria no pensamento filosófico pela primeira vez com Kant, quando ele relaciona suas reflexões críticas a uma análise sobre o momento singular em que está vivendo. Para Foucault, é em um texto menor, em uma resposta à pergunta "Was ist Aufklärung" (O que são as luzes?) de um jornal berlinense, que Kant proporciona um esboço do que o pensador francês chamou de atitude de modernidade. A Modernidade deixa então de ser entendida como um período e passa a ser uma relação que se deve estabelecer com seu tempo. É a partir dessa atitude que podemos conceber o que somos; o que somos não como identidade, mas como sujeitos históricos constituídos por determinadas práticas. Esse êthos filosófico permitiria, assim, uma crítica daquilo que somos e do que estamos nos tornando, crítica que é, ao mesmo tempo, "análise histórica dos limites que nos são colocados e prova de sua ultrapassagem possível” (Foucault, 2008, p. 351).

Kafka e Foucault foram, portanto, modernos. Produziram histórias escritas do ponto de vista dos homens mergulhados em seu cotidiano, histórias que têm sujeitos menores, anônimos, não heróis aos quais se voltam os holofotes $\mathrm{da}$ história tradicional. Infames que interrompem verdades imaculadas da história. Em Aracaju, também se ensaiavam os desafios da literatura. A "Veia do Shopping" fazia do seu corpo uma superfície de acontecimentos que negavam a conclusividade de uma mensagem edificante, ou a clareza de uma moral prescritiva. Como Kafka, transtornava boas consciências, negava o bálsamo para dores que não eram somente dela, turvava o vislumbre de salvação proposta por qualquer horizonte. Os gestos do seu dia a dia faziam do cotidiano uma afiada lâmina que cortava e interrompia a solidez de uma análise à espera do fim.

As ideias de Walter Benjamin acerca da narrativa aproximam-se dessa interrupção. O "historiador materialista", aproximando-se da figura do narrador, em vez de propor uma história linear, na qual um passado homogêneo e vazio desembocaria em seu presente, deveria ser capaz de perceber os indícios de uma outra história; este deveria constituir uma "experiência" com o passado. Ele faz do passado uma experiência única e assim faz "saltar pelos ares o continuum da história" (Benjamin, 1994b).

A narrativa tradicional, diferente do romance e da informação, não carregaria a necessidade de encontrar uma explicação para o acontecimento, real ou ficcional. 
O romance parte da procura de um sentido para a vida e traz em si a necessidade de concluir a história, já a informação somente tem valor no momento em que é nova e deve ser plausível e controlável, compreensível "em si e para si”. O que não ocorreria com a narrativa, pois esta é aberta a possíveis desdobramentos e não tem compromisso com a "comprobabilidade" dos fatos. A narrativa tradicional e a fábula que fascinavam justamente por serem indiferentes ao verdadeiro e ao falso passam a ser substituídas por formas de narrar que devem ilustrar a vida de forma a deixar entrever aquilo que está escondido e diz de um sujeito psicológico.

Cada manhã recebemos notícias de todo o mundo. E, no entanto, somos pobres em histórias surpreendentes. A razão é que os fatos já nos chegam acompanhados de explicaçóes. [...] Metade da arte narrativa está em evitar explicações. [...] O extraordinário e o miraculoso são narrados com a maior exatidão, mas o contexto psicológico da ação não é imposto ao leitor. Ele é livre para interpretar a história como quiser, e com isso o episódio narrado atinge uma amplitude que não existe na informação (Benjamin, 1994a, p. 203).

Produzir informações não interessa ao modo de pesquisar que aqui se aposta; o uso de cenas do cotidiano e a possível utilização de notícias como fonte para a pesquisa não se propõe a um acúmulo de verdades do mundo as quais nos digam o que somos ou nos deem uma aterradora visão das misérias de nosso tempo. Não se pretende uma abordagem jornalística ao lidar com acontecimentos. Correr-se-ia o risco de transformá-los em fatos necessitados de verificabilidades e explicaçõos, as quais, por diversas vezes, são solicitadas aos "portadores do conhecimento"; a exemplo de profissionais "psi" que, no contato com a vida e com a morte, acabam gerenciando a ordem e a moral, retirando a possibilidade da criação de outras maneiras de existir e produzindo "mais um" no rol das vitimizações.

Quer-se aqui intensificar a aposta na possibilidade de traçar narrativas menores. Esboçar modos de dizer o mundo que não aspiram à verdade e que não portam em si um fim alcançável, narrativas "abertas"; dimensão que, segundo Gagnebin, parece fundamental na obra de Benjamin e que estaria presente na estrutura da narrativa tradicional, um certo "não acabamento essencial" em que cada história é o ensejo para uma outra história (Gagnebin, 1994). E isso não compóe uma fuga da realidade ou ausência de compromisso no pesquisar em Ciências Humanas. Se aposta na produção de uma narrativa que possa dizer de nosso contemporâneo, porém não que o ilustre ou represente, mas que seja cortante. Um uso de cenas, mais do que cenas, de acontecimentos, que nos interpelem, que possam estilhaçar os limites do particular, que permitam entrever 
conexões com acontecimentos outros e que comportam diversas possibilidades, assim como as narrativas kafkianas.

No corpo daquela mulher, tempos díspares juntos a outros corpos misturavamse a seus odores. No shopping da cidade nordestina, espaços diversos atravessavam aquele lugar, maculando a clareza dos lugares assépticos. $\mathrm{O}$ manicômio, o sertão, imagens televisivas, templos do consumo e da fé, lugares sem nome perpassavam os poros do estabelecimento comercial. Das cenas particulares da "Véia do Shopping", desdobravam-se infinitas histórias sem protagonistas exclusivos. O cotidiano de Maria José Menezes Santos, cortante como uma lâmina afiada, oferecia a potência do escape aos pronomes pessoais. Eu, ela, eles ou nós embaçados na nitidez dos seus limites davam lugar a uma força impessoal que exigia atitude.

Entende-se que diferentes "histórias", distintos "usos" do passado podem ser aliados da aposta ética deste artigo no sentido de possibilitar a emergência de formas outras de narrar e de encarar o passado, tomando-o não como homogêneo e vazio, mas fundando uma experiência com ele e, assim, tornando-o repleto de "agoras", de acontecimentos inusitados que podem interpelar o nosso presente. A cidade, a loucura, o pesquisar adquirem, assim, um caráter processual em que suas variadas "formas" podem explodir e abrir caminho para outros modos de relação, isto é, processo do desdobramento do silêncio, como nos advertiu Blanchot.

Falar do contemporâneo convoca-nos a tomar uma atitude, a qual Foucault chamou de atitude de Modernidade, que nos permita que, ao mesmo momento em que nos distanciemos de nosso tempo, possamos apreendê-lo de maneira crítica e transfiguradora. Requer coragem e a capacidade de, mediante o excesso de informações e de luzes que nos ofuscam os olhos, apreender nessa mesma luz aquilo que existe de obscuro, de inominável. Escuro este que, para Agamben (2009), na verdade, diz de uma luz que vem até nós, mas que nunca nos alcança.

O contemporâneo não é apenas aquele que, percebendo o escuro do presente, nele apreende a resoluta luz; é também aquele que, dividindo e interpolando o tempo, está à altura de transformá-lo e de colocá-lo em relação com os outros tempos, de nele ler de modo inédito a história, de "citá-la" segundo uma necessidade que não provém de maneira nenhuma de seu arbítrio, mas de uma exigência à qual ele não pode responder. É como se aquela invisível luz, que é o escuro do presente, projetasse a sua sombra sobre o passado, e este, tocado por esse facho de sombra, adquirisse a capacidade de responder às trevas do agora (Agamben, 2009, p. 72). 
A produção de determinada narrativa pode-se apresentar, dessa maneira, como um meio de potencializar uma atitude de contemporaneidade em relação ao presente. E mostrar-se como encaminhamento metodológico para o engendramento de uma pesquisa que não sirva a um ideal normalizador, mas que seja sensível às interpelações cortantes do agora. Seria então um modo de fugir àquela paranoia unitária e totalizante de que nos alertou o pensador francês.

No diálogo com autores como Foucault, Barthes, Benjamin, entre outros, considera-se que o narrar pretendido sobre a cena urbana que direciona este artigo difere do dizer do outro, pelo outro ou contra o outro de que nos alerta Aquino. Tomando a diferença como portadora de uma capacidade de alterização, a ética que deve balizar o modo de se fazer pesquisa deve possibilitar um encontro desestabilizador com a loucura, com a cidade, com o presente. Encontro que possibilite a afirmação da polissemia política do que seja a urbe e a diferença, e que ponha à prova práticas que se querem inclusivas. "Um encontro marcado por nenhuma volúpia descritivo-normalizadora e alguma porosidade à diferença e à variância que esse tipo de acontecimento pode nos ocasionar, ou ao que quer que a alteridade nos afete e nos faça deslocar" (Aquino, 2008, p. 5).

Narrar se torna uma potente ferramenta conforme tais casos narrados possam remeter a um plano político. Quando faz explodir os limites de uma particularidade, permitindo conceber as forças que a atravessam e fazendo com que uma história possa se desdobrar em diversas outras. Histórias abertas, portanto. Singulares, mas que têm a força de produzir o inacabamento do silêncio. A queda da "Véia do Shopping" traduzida em tacere, o emudecer que faz falar, mas dissipa a força da palavra, o calar-se, foi mais um suicídio fruto do sofrimento psíquico de uma usuária da saúde mental. Suicídio ruidoso que a faz confessar, que engessa as bordas do seu corpo, impedindo que sua história possa se desdobrar em outras.

Apostamos, neste artigo, no silere desse ato, no silêncio desdobrador de sentidos, impossível de ser concluído como uma história linear. Ouvir o silêncio dessa mulher e o impacto de seu corpo com o chão como silere, silêncio do ainda não, mostra-se como uma recusa a considerar sua morte como confissão. Confissão que a faria dizer "sou louca", que comprovaria diagnósticos e a estrangularia numa fixa identidade. O suicídio, não descartando o caráter trágico que tem a perda de uma vida, ao ser encarado como confissão de um eu, tornarlhe-ia apenas uma vítima. A morte produziria incômodos, mas correria o risco de permanecer exclusivamente no âmbito das emoçôes; provocando tristeza, lamento, pena, porém a impedindo de recusar aquilo que "era". Retiraria, logo, sua possibilidade de deslocar, de aturdir, ou seja, de ser tomada como acontecimento que pode questionar mundos e interpelar as relações que produzem a diferença no contemporâneo. 
A queda daquele corpo tem a chance de interromper compactas convicções, exigir o estranhamento de otimismos e pessimismos da atualidade. Poderá pôr à prova verdades que fundamentam inquestionáveis humanismos. Ouvir seu silêncio talvez seja uma proposta ética que faça da diferença um promissor aturdimento. 


\section{REFERÊNCIAS}

Agamben, G. (2009). O que é o contemporâneo? e outros ensaios. Chapecó: Argos.

Albuquerque Júnior, Durval M. (2004). No castelo da história só há processos e metamorfoses, sem veredicto final. In E. Passetti, Kafka, Foucault: sem medos. (pp. 13-32). Cotia: Ateliê.

Aquino, J. G. (2008). A (auto)biografia como estilística da existência: o caso de Santiago de João Moreira Salles. In Anais 1 Colóquio Nacional Michel Foucault: educação, filosofia, história - transversais, 2008, Uberlândia: EDUFU.

Baptista, L. A. S. (2010). Noturnos urbanos: interpelações da literatura para uma ética da pesquisa. Estudos e Pesquisas em Psicologia, Ano 10(1),103-117. Recuperado a partir de http://pepsic.bvsalud.org/pdf/epp/v10n1/v10n1a08.pdf

Barthes, R. (2003). O neutro. São Paulo: Martins Fontes.

Benjamin, W. (1994a). O narrador: considerações sobre a obra de Nicolai Leskov. In W. Benjamin, Magia e técnica, arte e política: ensaios sobre literatura e história da cultura. (pp. 197-221). São Paulo: Brasiliense.

Benjamin, W. (1994b). Sobre o conceito da História. In: W. Benjamin, Magia e técnica, arte e politica: ensaios sobre literatura e história da cultura. (pp. 222234). São Paulo: Brasiliense.

Blanchot, M. (2005). O livro por vir. São Paulo: Martins Fontes.

Caiafa, J. (2002). Comunicação e diferença nas cidades. Lugar comum: estudos de mídia, cultura e democracia, 18,91-102.

Foucault, M. (1979). Nietzsche, genealogia e a história. In M. Foucault, Microfisica do poder. Rio de Janeiro: Graal.

Foucault, M. (1980, junho-março). Entrevista: Conversazione con Michel Foucault. Entrevista concedida a D. Trombadori em 1978. Il Contributo, 4(1), 23-84.

Foucault, M. (1988). História da sexualidade I: a vontade de saber. Rio de Janeiro: Graal.

Foucault, M. (1992). A vida dos homens infames. In M. Foucault, O que é um autor? Lisboa: Passagens. 
Foucault, M. (1993). O anti-Édipo: uma introdução à vida não fascista. Cadernos de Subjetividade / Núcleo de Estudos e Pesquisas da Subjetividade do Programa de Estudos Pós-Graduados em Psicologia Clínica da PUC-SP, 1(1), 197-200.

Foucault, M. (2008). O que são as luzes? In M. Foucault, Ditos e escritos II: arqueologia das ciências e história dos sistemas de pensamento. E. Monteiro (trad.). (pp. 335-351). Rio de Janeiro: Forense Universitária.

Gagnebin, J. M. (1994). Walter Benjamin ou a história aberta. In W. Benjamin, Magia e técnica, arte e política. (pp. 7-20). São Paulo: Brasiliense.

Rodrigues, H. B. C. (2009). Para desencaminhar o presente psi: biografia, temporalidade e experiência em Michel Foucault. In N. Guareschi \& S. Hüning. Foucault e a psicologia. (pp. 7-28). Porto Alegre: EdiPUCRS. 